\title{
Alga Species Diversity of the Natural Park "Borovoye"
}

\author{
Satbay Nurashov, EImira Sametova \\ Institute of Botany \& Phytointroduction Ministry of Education and Science, laboratory of Mycology and Algology, Almaty, Republic \\ Kazakhstan
}

\author{
Email address: \\ nurashs@mail.ru (S. B. Nurashov), elyasam@mail.ru (E. Sametova)
}

\section{To cite this article:}

Satbay Nurashov, Elmira Sametova. Alga Species Diversity of the Natural Park "Borovoye”. American Journal of Environmental Protection. Special Issue: Applied Ecology: Problems, Innovations. Vol. 4, No. 3-1, 2015, pp. 78-81. doi: 10.11648/j.ajep.s.2015040301.23

\begin{abstract}
The work was carried out within the project "Algae-flora of lake systems of Kokshetau-Borovoye, development of the recommendations about fighting against species of micro- and macro-algae causing oozing and "blossoming" of ponds in mass people recreation zones". Sample collecting was made during the expedition trips at summer season from the lakes Akkol, Lebedinoye and from the several region lakes such as Borovoye, Schuchiye, Bolshoye and Maloye Chebachye, Lebiyazhiye, Maybalyk, Katarkol and Shalkar. As a result of cameral processing and preliminary identification of the collected material more than 231 alga species were defined: Bacillariophyta - 151; Chlorophyta - 46; Cyanophyta - 16, Dinophyta - 4; Charophyta - 6; Euglenophyta -7 and Chrysophyta - 1. Alga species and their distribution by systematic groups were determined. They belong to 71 genera, 39 families, 24 orders, 11 classes and 7 departments. The greatest species variety was belonged to Bacillariophyta and Chlorophyta alga species. Often seen, dominating and causing water "blossoming" alga species of all departments were revealed in lakes Akkol and Bolshoye Chebachye. Mass development was demonstrated by the species Anabaena flos-aquae Breb. ex Born. et Flah. and species of the genus Oscillatoria Vauch. ex Gom. On the stones there were revealed mucilaginous yellow-brown fouling of Bacillariophyta algae such as Gomphonema, Synedra and Melosira. Reasons of mass development of the activators of blossoming and oozing of the ponds were revealed. They were caused by: increase of the content of nitrates, phosphates and other nutrients in the water; washouting the non-organic fertilizers from the nearest hills and fields; sedimentary waters coming into the ponds. The abstract and the biological description of the alga species (231 species of 7 departments) revealed in the lakes of the studied territories were made. Among found algae the perspective species of Chlorophyta and Charophyta algae for purification of the polluted waters were marked out.
\end{abstract}

Keywords: Natural Park, Lake, Algae, Kazakhstan

\section{Introduction}

Anthropogenic disturbance of the natural balance of water bodies some algae species can cause processes affecting the life of reservoirs, reducing the quality of water which becomes unsuitable for aquatic organisms and economic needs of people.

Due to intense anthropogenic impactat the "Borovoye" lake ecosystems the following events take place: the accelerated sedimentation of bottom of the reservoirs, water quality deterioration, unavailability of water bodies for recreational, fishing and other useful purposes. A sharp increase inload, especially in the areas of mass rest of the people leads to an increase in revenues in ponds of various organic wastes that greatly exceeds the ability of aquatic ecosystems to cleanse itself. This, inturn, contributes to the rapid growth of many harmful toxic microalgae and macrophytes. Settling on the bottom of water bodies, they accelerate the process of anaerobic decay; create conditions for rapid growth of benthic organisms - micro- and macro algae and higher aquatic macrophytes that is the root cause of the sedimentation and water-bloom.

The State National Natural Park "Borovoye"is located in the Akmola area and it was established in August, 2000. The territory of the SNNP "Borovoye" is a part of Kokshetau steppe, forest-steppe and ridged small mound upland. The climate is sharp-continental with hot summers and cold winters. Modern structure of landscapes within the park is represented by steppe, lake, forest, forest-steppe landscapes and landscapes of lowlands.

The State National Natural Park "Borovoye"is located in the Akmola area and it was established in August, 2000. The territory of the SNNP "Borovoye" is a part of Kokshetau steppe, forest-steppe and ridged small mound upland. The 
climate is sharp-continental with hot summers and cold winters. Modern structure of landscapes within the park is represented by steppe, lake, forest, forest-steppe landscapes and landscapes of lowlands.

The Kokshetau-Borovoye lake systems are located in the North of Kazakhstan, between Astana and Kokshetau cities. The highest point of the territory is Kokshetau mountain (Blue Mountain). In the territory of the Natural Park such large lakes as Shchuchiye, Borovoye, Bolshoye and Maloye Chebachiye and Katarkol were studied. In addition. such small lakes as Svetloye, Karasiye, Gornoye and Lebedinoye were also studied.

The aims of this study were: - to determine the species composition of algal flora and vascular aquatic plants of the lake system, including water-bloom pathogens and sedimentation of water bodies in the areas of mass recreation; - to study biology and ecology of these pathogens and the conditions for development and mass distribution of the species.

This work was directed to studying the algal flora in the Kokshetau-Borovoye lake systems due to the deterioration of water quality in water bodies of the region. The following tasks were formulated: - collecting the material-samples of algae from ponds in the Kokshetau-Borovoye lake systems; establishing the algae species; - determination the cause of the mass development of water-bloom pathogens and sedimentation of water bodies in recreational areas in the region. As well as identifying the dominant and causing water-bloom species of algae; making recommendations for the conservation of water bodies in the State National Natural Park (SNNP) "Borovoye".

\section{Study Area and Methods}

During 2012-2014 algae from the water bodies of the SNNP "Borovoye" were the objects of our researches. Expedition trips by means of the route inspection and permanently in the advance planned places and during different seasons of the year were the methods of our researches. While collecting algae the weather conditions, air and water temperatures were noted, transparency of water was determined by Secchi disk, chromaticity - by $\mathrm{pH}$-universal indicator paper. The standard classical hydrobotany and algology methods were used. Phytoplankton tests for the qualitative analysis were selected by the Apstein planktonic network made of silk gas No. 76, 45 $\mathrm{cm}$ diameter using methods of M.M. Gollerbakh and V.N. Polyansky, N. P. Masyuk, etc. [1, 2].

Samples of benthos and fouling from stones and boulders were taken by the scalpel; floating "flat cakes" were gathered with hands or rakes. In winter the samples were gathered from under the ice, for this purpose the drill and bathometer were used. Collected material was fixed in places of collecting by $4 \%$-formalin solution. While collecting the material data of occurrence of macrophytes, their quantity and forms of colonies of characteristic algae, color and nature of the samples were registered. Processing the material was made only after the end of field researches. Cameral processing of the samples was carried out in two steps, at first blue-green, green, euglenophyta, chrysophita and dinophyta algae were determined, then part of the samples were cleared from various mixtures and the identification of the diatoms was started. Specimens of diatom species were made by a calcinating method. The material washed from formalin was applied to the cover glass and calcinated on the electric stove. For definition of the diatoms the constant specimens were prepared. Cleaning the diatom frustules from organic substances was carried out by boiling in strong acids.

Observation over the morphology of algae was carried out by means of the light microscopeMBI- 3 and by the binocular microscope Motic BA 400 with the digital camera and the computer, the sizes of cells were measured with the eye-piece-micrometer, processing and definition of material were carried out according to the general accepted techniques of the algology and hydrobiology researches [3-18].

\section{Results and Discussion}

At studying the algal flora in the Borovoye lake systems during the summer, autumn and winter periods for clarification of specific structure and regularity of distribution of algae more than 200 samples of micro algae (plankton, benthos and fouling) were collected by us. In all water bodies the existence of the vascular water plants and chara algae were revealed, in some lakes their mass development was observed.

As a result of processing the assembled alga samples from the studied water bodies 231 species and varieties were revealed: - 151 diatom species; - 46 green alga species; - 16 blue-green alga species; - 7 euglenophyta species; - 4 dinophyta species; - 1 chrysophyta species and 6 chara alga species. The found species belong to 71 genera, 39 families, 24 orders, 11 classes and 7 departments (Table 1).

The diatoms differed in specific wealth (Bacillariophyta). The following genera were especially numerous: Navicula Bory - 19 species; Nitzschia Hass. - 12; Pinnularia Ehr.-10; Gomphonema Ag. - 9; Cymbella Ag. - 8; Eunotia Ehr. - 7, Fragilaria Lyngb. - 7, Surirella Turp. - 7. The most often met species were: Rhoicospheinia curvata (Kutz.) Grun, Cymbella ventricosa Kutz., Gomphonema acuminatum Ehr., G. constrictum Ehr., G. olivaceum (Lyngb.) Kutz., Cocconeis placentula Ehr., Caloneis silicula (Ehr.) Cl., Navicula cuspidata Kutz., N. bacillum Ehr., N. criptocephala Kutz., N. radiosa Kutz., Gyrosigma spenceri (W. Sm.) Cl., Amphora ovalis Kutz., Nitzschia hungarica Grun., N. tryblionella Hautzsch., N. sigma (Kutz.) W. Sm., N. sigmoidea (Ehr.) W. Sm., Epithemia zebra (Ehr.) Kutz., Rhopalodia gibba (Ehr.) O. Mull., Surirella ovalis Breb. and Cymatopleura solea (Breb.) Sm.

Green algae, (Chlorophyta), by number they were at the $2^{\text {nd }}$ place (46 species or $19.91 \%$ of the total algae species). There were met some species from the orders Desmidiales and Chloroococcales. The largest number of species was noted in the genera Cosmarium Corda., Scenedesmus Meyen., Ankistrodesmus Corda., Staurastrum Meyen. and Pediastrum Meyen.On the shores there were met such species as: 
Cladophora glomerata (L.) Kutz. and Ulothrix zonata Kutz.

In the lakes Borovoye and Bolshoye Chebachiye there were found Chlorococcophyceae species of such genera as Scenedesmus Meyen., Ankistrodesmus Corda. And Pediastrum Meyen. Especially often there were met such species as: Scenedesmus acuminatus (Lagerh.) Chod., and $S$. quadricauda (Turp.) Breb., S. obliquus (Turp.) Kuetz.,S. acutus Meyen., S. falcatus Chodat., S. ellipticus Corda., Ankistrodesmus fusioformis Corda., A. falcatus (Corda) Ralfs., A. gracilis (Reinsch) Korsch., Pediastrum boryanum (Turp.) Menegh., P. duplex Meyen., P.angulosum (Ehr.) Menegh. and P. tetras (Ehr.) Ralfs. (Table 1).

Table 1. Taxonomical structure of sea algae in the lake systems of the SNNP "Borovoy".

\begin{tabular}{|c|c|c|c|c|c|c|}
\hline \multirow{2}{*}{ Division } & \multicolumn{6}{|c|}{ Number } \\
\hline & classes & orders & families & genera & species & $\%$ from the total number of species \\
\hline Bacillariophyta & 3 & 13 & 20 & 33 & 151 & 65.37 \\
\hline Chlorophyta & 2 & 4 & 9 & 20 & 46 & 19.91 \\
\hline Cyanophyta & 2 & 3 & 6 & 9 & 16 & 6.93 \\
\hline Euglenophyta & 1 & 1 & 1 & 3 & 7 & 3.03 \\
\hline Dinophyta & 1 & 1 & 1 & 3 & 4 & 0.73 \\
\hline Chrysophyta & 1 & 1 & 1 & 1 & 1 & 0.43 \\
\hline Total: & 11 & 24 & 39 & 71 & 231 & 100 \\
\hline
\end{tabular}

Green algae, (Chlorophyta), by number they were at the $2^{\text {nd }}$ place (46 species or $19.91 \%$ of the total algae species). There were met some species from the orders Desmidiales and Chloroococcales. The largest number of species was noted in the genera Cosmarium Corda., Scenedesmus Meyen., Ankistrodesmus Corda., Staurastrum Meyen. and Pediastrum Meyen.On the shores there were met such species as: Cladophora glomerata (L.) Kutz. and Ulothrix zonata Kutz.

In the lakes Borovoye and Bolshoye Chebachiye there were found Chlorococcophyceae species of such genera as Scenedesmus Meyen., Ankistrodesmus Corda. And Pediastrum Meyen. Especially often there were met such species as: Scenedesmus acuminatus (Lagerh.) Chod., and $S$. quadricauda (Turp.) Breb., S. obliquus (Turp.) Kuetz.,S. acutus Meyen., S. falcatus These alga species developing in large numbers, causing water-bloom can become the reason of fish death and poisonings.

In the studiedwater bodies there were found two families of the order Desmidiales (Desmidiaceae) of the 7 genera, 19 species and 2 forms. We often met Desmidiaceae from the genera Cosmarium Corda and Staurastrum Meyen. From the genus Cosmarium Corda there were found: Cosmarium regnesii Reinsch., C. angulosum Breb,. C. impressulum Elfv., $C$ subimpressulum Borge., C. gayanum De Toni., $C$. gostyniense (Racib.) Gronbl., C. venustum (Breb.) Arch., $C$. venustum var. hypohexagonum West., $C$. botrytis Menegh., $C$. retusum var. in aequal ipellicum W. et G.S. West. And $C$. granatum Breb.

From the Dinophyta there were found four species Ceratium hirundinella (O. F. Mull.) Bergh., Peridiniopsis penardii (Lemm.) Bourr. Peridinium aciculiferum Lemm. and Peridinium lomnickii Wolosz.

In the lakes Bolshoye Chebachiye and Borovoye, Maloye Chebachiye, Katarkol and Shchuchiye among vascular aquatic plants there were met Chara algae - Charatomentosa L., Characanescens Desv.et Lois. C. kirghisorum Lessingemend. Hollerb and Nitella confervacea A. Br. On these Chara species there were found periphyton species such as: Cocconeis placentula Ehr., Cymbella ventricosa Kutz. and Rhoicospheinia curvata (Kutz.) Grun.
The lakes Borovoye, Lebiazhiye and Shchuchiye are freshwater ponds, and the lakes Bolshoye Chebachiye, Maloye Chebachiye, Maibalyk and Katarkol are brackish. The exsicating lake Akkol was water-logged, on its shore there were found fouling of blue-green algae especially often there were met species of the Oscillatoria Vauch. ex Gom genus. In the estern part of the lake Shchuchiye there were met vascular aquatic plants. They formed tangles made of macereed, water spike, bur-reed and chara alga species such as Charatomentosa L. and Characanescens Desv. et Lois. Also these species were noted in the lakes Katarkol, Maloye Chebachiye and Lebiazhiye. In the lake Chebachiye there was noted water-bloom of blue-green algae, among them especially dominant was Anabaena flos-aquae Breb. ex Born. et Flah. This toxic species was the cause of water-bloom of the reservoir. Also on the stones there was found limy yellow-brown fouling of diatoms species of the genera Gomphonema and Synedra. By the composition of algal flora the lake Borovoye, Bolshoye Chebachiye, Shchuchiye and Katarkol are moderately polluted lakes, and the lake Maloye Chebacheis more or less clean.

From the Euglenophyta species we met species from the genera Euglena, Leposinclis and Trahelomonas.

From the Chrysophyta species in the lake Borovoye there were found only one species Dinobryon divergens O.E. Imhof.

In the study of yellow-brown patina of the coastal stones it was found that the dominant species were species of the genera Gomphonema, Synedra from the diatoms. Also, we have identified species of algae causing water bloom and sedimentation of water bodies (Lakes Akkol and Bolshooye Chebachiye), blue-green algae: Anabaena flos-aquae Breb. ex Born. et Flah., Anabaena constricta (Szaf.) Geitl., Microcystis aeruginosa (Kutz.) Kutz., Oscillatoria brevis (Kutz.) Gom. From green algae: Scenedesmus acuminatus (Lagerh.) Chod., S. quadricauda Chod., S. obliiqus (Turp.); diatomas: Asterionella formosa Hass., Fragilaria crotonensis Kitt.

It was noted that when there were water-bloom processes in the water bodies mainly one or several microalgae species dominated, usually confined to such eutrophic environments. In such conditions, other species stop their development or 
precipitate. When the water bloom-season elapses, these species again begin their development.

There were alga species which were not found in summer time, but were found in winter samples in the lake Bolshoye Chebachiye (Fragilaria leptostauron (Ehr.) Hust., Amphiprora paludosa W. Sm., Mastogloia grevillei W. Sm., Rhopalodia parallela (Grun.) O. Mull., Navicula binodis Ehr., Campylodiscus noricus Ehr). They belong to the benthos species; their sizes are in several times higher than the planktonic species. Among these benthos species the plankton species were found in small quantities. While view in gunder a microscope it was clear that almost all species had the protoplast of green-yellow-brown color. It means that all of the detected species under the ice are located in optimum conditions.

Almost in all studied water bodies the tangles of the vascular water plants which participate in the process of purification of the muddy waters were found, lots of planktonic algae settle on the bottom of the water bodies and symbiotic epiphytes grow on them. Lots of vascular water plants from the genera Potamogeton, Najas, Sparganium, Scirpus, and Typha were found.

As a result of researches of the water bodies of the SNNP "Borovoye" the recommendations about the fight against sedimentation and water-bloom in recreational zones were made. Strict observance of sanitary and preventive norms in the recreational territories aimed at restriction of receipt of organic and other waste in reservoirs is necessary. The organization and systematic carrying out the ecological-educational actions in places of mass concentration of vacationers and the organization of works on improvement of the territory of other neighboring lakes to remove overloads from the main reservoirs - Borovoye and Bolshoye Chebachiye are recommended.

\section{Conclusion}

As a result of the researches of the reservoirs of the SNPP "Borovoye" 231 species and varieties of algae relating to 71 genera, 39 families, 24 orders, 11 classes and 7 departments were revealed.

The greatest specific variety was presented by diatom algae -151 species. The second place was taken by Green algae 46 species. Blue-green algae -16 species; Euglenophyta -7 , Chara algae -6 , Dinophyta -4 species.

In water bodies of the SNNP "Borovoye" during the whole vegetative period the diatom algae was dominant, it was noted that their specific quantity decreased in summer, in comparison with spring and autumn species. The quantity of species of green algae, on the contrary, in the summer increased and decreased in spring and in autumn.

Species of algae causing the water-bloom and sedimentation in the lakes Akkol and Bolshoye Chebachye were revealed, such as blue-green algae: Anabaena flos-aquae Breb. ex Born. et Flah., Anabaena constricta (Szaf.) Geitl., Microcystis aeruginosa (Kutz.) Kutz. and Oscillatoria brevis (Kutz.) Gom.
It was noted that the ecological structure of the alga flora of the water bodies of the SNNP "Borovoye" was formed by planktonic (80 species), benthophytes (125), fouling (47) and epiphytes (27) species.

\section{References}

[1] Hollerbach, MM, Polyansky VI ( 1951). Pres - novodnye algae and their study. Define - Tel freshwater algae USSR. The general part. "Soviet science", M.,199 p.

[2] Masuk NP, Kondratieff NV, Wasser SP (1989). Algae . Spravochnik.Kiev, 608 p.

[3] To freshwater algae USSR in 14 editions. (1951; 1953; 1982; 1983). M.

[4] To freshwater algae Ukrainian SSR. (1960). Vol. 11. Diatoms. Kiev. 412.

[5] Lothar Kalbe. (1980). Kieselalgen in Binnengewassern. Diatomeen. Wittenberg Lutherstadt, 206 p.

[6] Round F.E., Crawford R.M., Mann D.G. (1990). The Diatoms. Biology and morphology of the genera. Cambridge Univ. Press. $747 \mathrm{p}$.

[7] P. Carenko Short determinant Chlorococcales algae Ukrainian SSR. (1990). Kiev. 198.

[8] Ergashev AE Qualifier Protococcales algae Central Asia. (1979). Vol. 1-2. Tashkent. 344 p., 384 p.

[9] Genkal SI, Kulikov MS, TM Mikheev, Kuznetsova IV, EV Lukyanov Diatoms plankton Svislach River and its reservoirs. M .: Science World, 2013. 236 p.

[10] Genkal SI Trifonov IS Diatoms of the plankton of Lake Ladoga and its basin reservoirs. Ed.: JSC "Rybinsk Printing House", 2009. $72 \mathrm{p}$.

[11] Barinova S.S., Medvedova L.A., Anissimova O.V. Biodiversity of algae-environmental indicators. Tel Aviv, 2006. 498 p.

[12] Barinova S.S., Medvedova L.A., Anissimova O.V. Diversity of algal indicators in Environmental Assessment. Tel Aviv: PiliesStudio, 2006, 498 p.

[13] Popovskaya GI Genkal SI, Likhoshvai EV Diatoms of the plankton of Lake Baikal: Atlas determinant. Novosibirsk: Nauka, 2002, 168 p.

[14] Dorofeyuk N.I., Kulikovskiy M.S. Diatoms of Mongolia. Moscow, 2012, 366 p.

[15] Lange - Bertalot. Diatomin im Subwasser- Benthos von Mitteleuropa. A.R.G. Gantner Verlag K.G. 908 p.

[16] Krammer K., Lange-Bertalot H. Bacillariophyceae. 1. Teil: Naviculaceae // SuBwasserflora von Mitteleuropa. 1986. Bd. $2 / 1.876 \mathrm{~s}$.

[17] Krammer K., Lange-Bertalot H. Bacillariophyceae. 2. Teil: Bacillariaceae, Epithemiaceae, Surirellaceae. SuBwasserflora von Mitteleuropa. 1988. Bd. 2/2. 536 p.

[18] Krammer K., Lange-Bertalot H. Bacillariophyceae. 3. Teil: Centrales, Fragilariaceae, Eunotiaceae. SuBwasserflora von Mitteleuropa. 1991a. Bd. 2/3. 576 p. 